\section{Preliminary Observations on the Traffic Tolerance of Four Seashore Paspalum Cultivars Compared to Hybrid Bermudagrass}

\author{
J.T. Brosnan ${ }^{1,2}$ and J. Deputy
}

AdDITIONAL INDEX wORDs. Paspalum vaginatum, Cynodon dactylon $\times$ Cynodon transvaalensis, Tifway 419, Cady Traffic Simulator, CTS, athletic field turf, football

Summary. Seashore paspalum (Paspalum vaginatum) is a prostrate, perennial turfgrass used on golf courses and athletic fields in warm-season climates. Research data on the traffic tolerance of seashore paspalum compared with hybrid bermudagrass (Cyndon dactylon $\times$ Cynodon transvaalensis) is minimal. A study was conducted in 2008 to evaluate the traffic tolerance of 'Sea Isle 2000', 'Salam', 'Sea Dwarf', and 'Sea Isle 1' seashore paspalum relative to 'Tifway' hybrid bermudagrass. Traffic was applied with a Cady Traffic Simulator (CTS) and traffic tolerance was assessed visually through measurements of percentage of turfgrass cover after $36,54,72$, and 90 passes were applied with the CTS. After 90 passes (45 simulated professional football games) with the CTS, 'Salam', 'Sea Dwarf', and 'Sea Isle 1' seashore paspalum exhibited greater traffic tolerance than 'Tifway' hybrid bermudagrass; 'Sea Isle 2000' seashore paspalum exhibited the least amount of traffic tolerance in this study. These data suggest that some seashore paspalum cultivars may be a suitable alternative to hybrid bermudagrass on athletic fields in warmseason climates.

S eashore paspalum is a prostrategrowing, perennial turfgrass, indigenous to tropical and coastal areas (Duncan and Carrow, 2000). While hybrid bermudagrass is still the most commonly used turfgrass on golf courses and athletic fields in Hawaii, the use of seashore paspalum is increasing (L. Gilhuly, personal communication). It has been reported that over $44 \%$ of golf course renovation projects in Hawaii in 2007 were established to seashore paspalum (J.T. Brosnan and J.R. Hollyer, unpublished data). The increased use of seashore paspalum on golf courses and athletic fields in Hawaii is related to its stress tolerance. Research has reported that seashore paspalum exhibits an improved tolerance to various biotic stresses, including shade

Department of Tropical Plant and Soil Sciences, University of Hawaii, 3190 Maile Way, Honolulu, HI 96822

The authors would like to thank Larry Thornton, superintendent at the National Memorial Cemetery of the Pacific, Southern Turf International, and Ali'i Turf for supporting this research.

Mention of products or trade names do not constitute endorsement by the University of Tennessee and are included as a reference only. These products should be used in accordance with the manufacturer's instructions.

${ }^{1}$ Current address: Department of Plant Sciences, University of Tennessee, 252 Ellington Plant Sciences Building, 2431 Joe Johnson Drive, Knoxville, TN 37996.

${ }^{2}$ Corresponding author. E-mail: jbrosnan@utk.edu.
(Jiang et al., 2004), variable soil $\mathrm{pH}$ (Duncan and Carrow, 2000), anaerobic soil conditions (Duncan and Carrow, 2000), drought (Carrow, 2005; Huang et al., 1997), reduced nitrogen fertility (Duncan and Carrow, 2000), and salinity (Duncan and Carrow, 2000; Lee et al., 2004; Marcum and Murdoch, 1990; Wiecko, 2003) compared with hybrid bermudagrass.

Traffic is an abiotic stress placed on all turfgrasses that imposes two forms of damage: wear and soil compaction (Carrow and Petrovic, 1992). Wear injury is characterized by the physical injury (tearing) of leaf tissues, whereas soil compaction negatively alters soil physical properties, affecting root growth (Carrow and Petrovic, 1992).

Researchers have found that certain growth characteristics affect seashore paspalum wear tolerance. Trenholm et al. $(1999,2000)$ evaluated seashore paspalum wear tolerance and reported that cultivars with a fine leaf texture, increased shoot density, and increased vertical growth rate exhibited wear tolerance similar to 'Tifway' hybrid bermudagrass, a turfgrass commonly used on athletic fields and golf courses in warm-season climates for its superior traffic tolerance. New seashore paspalum cultivars such as 'Sea Isle 2000', 'Sea Isle l', 'Sea Dwarf', and 'Salam' were not evaluated in the work of Trenholm et al. $(1999,2000)$. Lee et al. (2004) reported that new seashore paspalum cultivars such as Sea Isle 2000, Sea Isle 1, and Salam have significantly greater vertical growth rates than 'Tifway' hybrid bermudagrass, which suggests that these cultivars may offer improved wear tolerance, although wear tolerance was not directly evaluated in that study.

Currently, no research data exists on the traffic tolerance of seashore paspalum. Therefore, the objective of this research was to assess the traffic tolerance of four newly released seashore paspalum cultivars and 'Tifway' hybrid bermudagrass.

\section{Materials and methods}

Plot establishment and MAINTENANCE. Experimental plots were constructed at the National Memorial Cemetery of the Pacific (Honolulu, HI) in Oct. 2007. Before establishment, the entire experimental area received two applications of glyphosate plus fluazifop-P-butyl at rates of $5 \mathrm{lb} /$ acre a.i. and $0.37 \mathrm{lb} /$ acre a.i., respectively, to eradicate existing vegetation. Existing sod was removed from the site $20 \mathrm{~d}$ after the second herbicide application with a sod cutter (model 544853C; Ryan, Johnson Creek, WI). Testing of the

\begin{tabular}{lllc}
\hline $\begin{array}{l}\text { Units } \\
\text { To convert U.S. to SI, } \\
\text { multiply by }\end{array}$ & U.S. unit & SI unit & $\begin{array}{l}\text { To convert SI to U.S., } \\
\text { multiply by }\end{array}$ \\
\hline 0.4047 & $\mathrm{acre}(\mathrm{s})$ & $\mathrm{ha}$ & 2.4711 \\
0.3048 & $\mathrm{ft}$ & $\mathrm{m}$ & 3.2808 \\
9.2903 & $\mathrm{ft}^{2}$ & $\mathrm{dm}^{2}$ & 0.1076 \\
0.0283 & $\mathrm{ft}^{3}$ & $\mathrm{~m}^{3}$ & 35.3147 \\
2.54 & inch(es) & $\mathrm{cm}$ & 0.3937 \\
25.4 & inch(es) & $\mathrm{mm}$ & 0.0394 \\
0.4536 & $\mathrm{lb}$ & $\mathrm{kg}$ & 2.2046 \\
1.1209 & $\mathrm{lb} / \mathrm{acre}$ & $\mathrm{kg} \cdot \mathrm{ha}^{-1}$ & 0.8922 \\
0.9144 & yard(s) & $\mathrm{m}$ & 1.0936 \\
0.8361 & yard & $\mathrm{m}^{2}$ & 1.1960
\end{tabular}


underlying Tantalus silty clay loam soil (ferrihydritic, isothermic Typic hapluands) revealed no nutrient deficiencies and a mean soil $\mathrm{pH}$ of 7.7. A starter fertilizer $(6 \mathrm{~N}-8.8 \mathrm{P}-16.6 \mathrm{~K})$ was applied to the entire experimental area at a rate of $57.4 \mathrm{lb} /$ acre. Elemental sulfur was also applied at a rate of $43.4 \mathrm{lb} /$ acre to lower soil $\mathrm{pH}$. In Hawaii, applications of sulfur before establishment are common, as most native soils are alkaline in nature. This application of sulfur before establishment yielded no negative effects on turfgrass quality in this study.

Four seashore paspalum cultivars were evaluated in this study: Sea Isle 1, Sea Dwarf, Salam, and Sea Isle 2000. A single hybrid bermudagrass cultivar, Tifway, was evaluated for comparison. Experimental plots (10 $\times 8 \mathrm{ft}$ ) were established on 26 Oct. 2007. Plots established to 'Sea Isle 2000' were vegetatively propagated at a rate of 740 bushels/acre, where 1 bushel is equal to the amount of plant material harvested from 1 yard $^{2}$ of sod (McCarty and Miller, 2002). Stolons were spread across the surface of each plot by hand and were topdressed $(\approx 1 / 8$ to $1 / 4$ inch deep $)$ with hydromulch (NaturesOwn High Density Paper Hydroseeding Mulch; Hamilton Manufacturing, Twin Falls, ID) and tackifier (NaturesOwn C:tac, Hamilton Manufacturing). Stolonized plots achieved 100\% turfgrass cover on 27 Nov. 2007. All other cultivars in this study were established from sod; after installation, sod seams were filled with silica sand topdressing that conformed to U.S. Golf Association (USGA) particle size specifications (USGA, 2007) and were rolled by hand with a $165-1 b$ roller.

Plots were maintained at a 1.5inch height of cut with a walk-behind reel mower (model H20R; Tru-Cut, Gardena, CA). Plots were mowed twice weekly and clippings were removed. Plots were fertilized monthly with a quick-release nitrogen source $(10.0 \mathrm{~N}-1.8 \mathrm{P}-13.3 \mathrm{~K})$ at a rate of $43.4 \mathrm{lb} /$ acre $\mathrm{N}$ and were irrigated with potable water (City and County of Honolulu, Honolulu, HI) using an in-ground sprinkler system, on an asneeded basis, to prevent the onset of moisture stress. Plots were vertically mowed to remove excess organic debris (thatch) from the soil-turfgrass interface on $21 \mathrm{Feb}$. 2008. All plots received two passes with a vertical mower (model 1321; AeroKing, Jacobsen, Charlotte, NC) set to a l/ 2 -inch depth. Debris brought to the surface was removed by hand. After vertical mowing was complete, a light $(\approx 1 / 8$ inch) layer of silica sand topdressing was applied to each plot. Silica sand topdressing conformed to USGA particle size specifications (USGA, 2007).

Treatments evaluated. Plots were split with varying levels of simulated traffic. Simulated traffic was applied with a Cady Traffic Simulator (CTS) developed according to the methods of Henderson et al. (2005). The CTS is a modified, walk-behind, core-cultivation unit (model 544872, Greensaire 24; Ryan) fitted with fabricated "feet" that are attached to the core heads instead of coring tines. These feet alternately strike the turfgrass surface as the machine moves to simulate the dynamic forces characteristic of traffic stress. Two passes with the CTS creates the same number of cleat marks per square meter that one National Football League (NFL) game would produce between the hashmarks at the 40 -yard line (Henderson et al., 2005). Researchers (Calhoun et al., 2002; Vanini et al., 2007) have found that the CTS produces more intense traffic than the Brinkman Traffic Simulator (BTS), developed by Cockerham and Brinkman (1989), due to differences in cleat surface area between the two devices (Henderson et al., 2005). Two levels of traffic were evaluated in this study: no traffic and high traffic (18 passes per week with the CTS). Traffic treatments were initiated on 18 Mar. 2008 and concluded on 22 Apr. 2008 after a total of 90 passes (45 games) had been applied with the CTS.

Data collected. Traffic tolerance was assessed visually by estimating the percentage of turfgrass cover on each plot (Minner et al., 1993). Visual turfgrass cover ratings were made weekly from 18 March to 22 Apr. 2008 after 36, 54, 72, and 90 passes $(18,27,36$, and 45 simulated professional football games) had been applied with the CTS.

Shoot density was measured by counting shoots from four 2.4-inchdiameter plugs removed from each whole plot $(10 \times 8 \mathrm{ft})$ on 11 Mar. 2008 before the initiation of traffic treatments. The top portion of each plug was removed with a knife at crown level and the number of upright shoots were counted and recorded. Other researchers (Kopec et al., 2007) have used this method to assess the shoot density of various seashore paspalum cultivars.

Surface hardness was measured using a Clegg Soil Impact Tester (CIST; Lafayette Instrument, Lafayette, IN) to assess the effects of traffic treatments on soil physical properties. Increases in surface hardness have been associated with increases in soil compaction common during traffic stress (Henderson et al., 1990; Rogers et al., 1988; Zebarth and Sheard, 1985). The CIST used in this study was equipped with a $2.25-\mathrm{kg}$ missile that was dropped from a height of $440 \mathrm{~mm}$ (American Society for Testing Materials, 2000; Clegg, 1976). Impact attenuation, measured by an accelerometer mounted on the missile, was used to indicate surface hardness and was reported as Gmax. Gmax is a unitless number representing the ratio of maximum deceleration of the missile upon impact, in units of gravities $(G)$, relative to the acceleration due to gravity (American Society for Testing Materials, 2000; Henderson et al., 1990). A single CIST measurement consisted of dropping the missile three times, with the average reported as Gmax. The average of eight Gmax values per subplot was used to represent the surface hardness (Gmax) of each subplot. Surface hardness data were collected before traffic was initially applied (11 Mar. 2008) and after traffic treatments were complete (12 May 2008). Volumetric soil moisture content was measured on each plot using a time domain reflectometry (TDR) probe (TDR 300; Spectrum Technologies, East Plainfield, IL), but was not an experimental factor in the study.

Statistical analysis. Three replications of each cultivar were arranged in a completely randomized design. Plots were split with varying levels of simulated traffic: no traffic and high traffic. Each $(10 \times 8 \mathrm{ft})$ whole plot was divided randomly into two $(8 \times 4.5 \mathrm{ft})$ subplots, receiving the high traffic or no traffic treatments. Data were analyzed using analysis of variance and a Fisher's least significant difference (LSD) was calculated when the F-ratio was significant at $\alpha=0.05$ (SAS 9.1; SAS 
Institute, Cary, NC). An LSD was not calculated when the F-ratio was not significant. Plots not receiving simulated traffic maintained $100 \%$ turfgrass cover for the duration of the experiment; thus, only data from subplots receiving simulated traffic will be presented.

\section{Results and discussion}

Turfgrass COver. Turfgrass seashore paspalum cultivars and between species. 'Sea Isle 2000' plots yielded the lowest turfgrass cover ratings on each rating date. After 72 passes with the CTS (36 simulated football games), turfgrass cover on 'Sea Isle 2000' plots averaged 10.4\% compared with $94.9 \%, 90.0 \%, 87.9 \%$, and $85.8 \%$ for 'Sea Dwarf', 'Salam', 'Sea Isle 1', and 'Tifway', respectively (Table 1). This response was also observed after 36, 54, and 90 passes of simulated traffic had been applied (Table 1). Despite the high vertical growth rate reported by Lee et al. (2004), data collected in this study suggest that 'Sea Isle 2000' exhibits poor traffic tolerance compared with not only 'Tifway' hybrid bermudagrass, but other seashore paspalum cultivars as well.

Few significant differences in traffic tolerance were reported between 'Tifway' and the three other seashore paspalum cultivars evaluated (Salam, Sea Dwarf, and Sea Isle 1). After 36, 54, and 72 passes with the CTS, all cultivars except Sea Isle 2000 had greater than $85 \%$ turfgrass cover (Table 1). After 90 passes with the CTS, 'Salam', 'Sea Dwarf', and 'Sea Isle 1' plots measured higher cover (traffic tolerance) varied among

in turfgrass cover than 'Tifway' (Table 1).

Shoot Density. The improved traffic tolerance of these seashore paspalum cultivars compared with 'Tifway' may be related to shoot density. Seashore paspalum cultivars exhibiting superior traffic tolerance, Salam and Sea Dwarf, measured higher in shoot density (before applying simulated traffic) than 'Tifway' (Table 2). Trenholm et al. (1999) reported a similar relationship between seashore paspalum shoot density and wear tolerance. 'Sea Isle 2000', the cultivar exhibiting the poorest traffic tolerance on each rating date, yielded the lowest shoot density values (123.9 shoots $/ \mathrm{dm}^{2}$ ). It is not clear whether the reduced density of 'Sea Isle 2000' was because plots were established from stolons instead of sod. Kopec et al. (2007) reported 'Sea Isle 2000' shoot density values greater than those in this study; however, plots in the work of Kopec et al. (2007) were maintained at a height of cut seven times lower than that which was used in this study. The data collected herein are preliminary and further research is needed to determine if the reduced shoot density of 'Sea Isle 2000' was due to establishment method or a function of the height of cut.

Surface HARDNESS. Significant increases in surface hardness were reported for every cultivar after applying 90 passes with the CTS (Table 3 ). Given that increases in surface hardness have been linked to increases in soil compaction (Clegg, 1976; Rogers et al., 1988), it is possible that the reported differences in turfgrass

Table 1. Turfgrass cover (traffic tolerance) ratings for seashore paspalum and hybrid bermudagrass plots after applying $36,54,72$, and 90 passes of simulated traffic with the Cady Traffic Simulator in 2008.

\begin{tabular}{|c|c|c|c|c|c|}
\hline \multirow[b]{3}{*}{ Cultivar } & \multirow[b]{3}{*}{$\mathbf{N}_{\mathbf{y}}$} & \multicolumn{4}{|c|}{ Simulated traffic (no. passes) } \\
\hline & & 36 & 54 & 72 & 90 \\
\hline & & \multicolumn{4}{|c|}{ Turfgrass cover $(\%)^{\mathrm{z}}$} \\
\hline Sea Isle $1^{\mathrm{x}}$ & 3 & 86.1 & 85.0 & 87.9 & 90.8 \\
\hline Sea Dwarf ${ }^{\mathrm{x}}$ & 3 & 94.2 & 93.3 & 94.9 & 80.8 \\
\hline Salam $^{\mathrm{x}}$ & 3 & 91.7 & 91.6 & 90.0 & 75.8 \\
\hline Tifway ${ }^{\mathrm{w}}$ & 3 & 97.1 & 95.8 & 85.8 & 29.6 \\
\hline Sea Isle $2000^{x}$ & 3 & 44.6 & 44.6 & 10.4 & 13.1 \\
\hline $\operatorname{LSD}(0.05)^{\mathrm{v}}$ & & 5.8 & 5.8 & 3.7 & 7.4 \\
\hline
\end{tabular}

${ }^{z}$ Visual assessment of the percentage of each plot covered by turfgrass (Minner et al., 1993).

${ }^{\mathrm{y}} \mathrm{N}=$ number of observations.

${ }^{x}$ Seashore paspalum.

wHybrid bermudagrass.

'LSD $(0.05)=$ Fisher's least significant difference value used to evaluate differences between cultivar means at $\alpha=0.05$. cover after trafficking (traffic tolerance) may be related to the ability of these cultivars to grow in compacted soils. For example, after 90 passes with the CTS, 'Sea Isle 1' measured higher in turfgrass cover than 'Tifway' (Table 1). Shoot density cannot

Table 2. Shoot density means for seashore paspalum and hybrid bermudagrass cultivars evaluated in 2008 before applying simulated traffic.

\begin{tabular}{lcc}
\hline Cultivar & N $^{\mathrm{z}}$ & $\begin{array}{c}\text { Shoot density } \\
\left(\text { shoots } / \mathbf{d m}^{2}\right)^{\mathrm{y}}\end{array}$ \\
\hline Sea Dwarf & 24 & 311.1 \\
Salam $^{\mathrm{x}}$ & 24 & 305.2 \\
Sea Isle 1 $^{\mathrm{x}}$ & 24 & 251.3 \\
Tifway $^{\mathrm{w}}$ & 24 & 244.9 \\
Sea Isle 2000 $^{\mathrm{x}}$ & 24 & 123.9 \\
${\text { LSD }(0.05)^{\mathrm{v}}}^{\mathrm{L}}$ & & 36.0 \\
\hline
\end{tabular}

${ }^{2} \mathrm{~N}=$ number of observations.

yShoot density measured according to the methods of Kopec et al., (2007); 1 shoot $/ \mathrm{dm}^{2}=9.2903$ shoots/ $\mathrm{ft}^{2}$.

'Seashore paspalum.

"Hybrid bermudagrass.

${ }^{v} \operatorname{LSD}(0.05)=$ Fisher's least significant difference value used to evaluate differences between cultivar means at $\alpha=0.05$

Table 3. Surface hardness means for seashore paspalum and hybrid bermudagrass plots receiving 0 and 90 passes of simulated traffic with the Cady Traffic Simulator in 2008.

\begin{tabular}{|c|c|c|c|}
\hline \multirow[b]{2}{*}{ Cultivar } & \multirow[b]{2}{*}{$\mathrm{N}^{\mathrm{y}}$} & \multicolumn{2}{|c|}{$\begin{array}{l}\text { Surface } \\
\text { hardness } \\
(\mathrm{Gmax})^{\mathrm{z}}\end{array}$} \\
\hline & & $\begin{array}{c}0 \\
\text { passes }^{x}\end{array}$ & $\begin{array}{c}90 \\
\text { passes }^{\mathrm{w}} \\
\end{array}$ \\
\hline Tifway $^{\mathrm{v}}$ & 24 & 51.7 & 89.1 \\
\hline Sea Isle $2000^{\mathrm{u}}$ & 24 & 57.9 & 87.0 \\
\hline alam $^{u}$ & 24 & 43.7 & 74.6 \\
\hline Sea Dwarfu & 24 & 46.1 & 72.8 \\
\hline ea Isle $1^{\mathrm{u}}$ & 24 & 35.5 & 53.0 \\
\hline$S D(0.05)^{\mathrm{t}}$ & 2.7 & 4.7 & \\
\hline \multicolumn{4}{|l|}{$\begin{array}{l}\mathrm{LSD}_{\text {time }} \\
\quad(0.05)^{\mathrm{s}}=4.1 \\
\end{array}$} \\
\hline \multicolumn{4}{|c|}{ 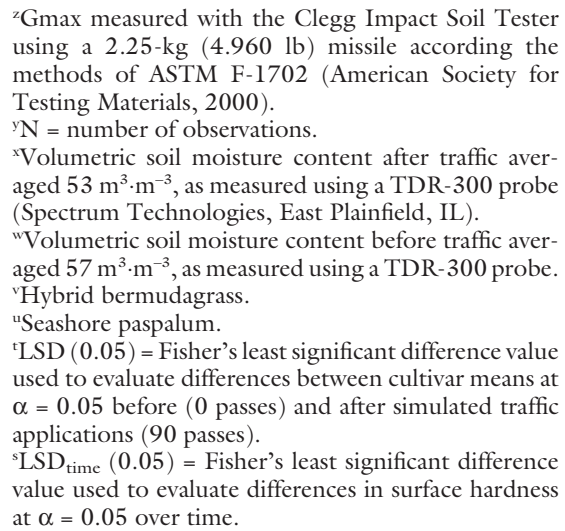 } \\
\hline
\end{tabular}


explain this difference in traffic tolerance, as shoot density means for each cultivar were not statistically different from one another before applying simulated traffic (Table 2). Huang et al. (1997) reported that 'Sea Isle l' exhibits a greater vertical growth rate than other warm-season turfgrasses in environments of reduced soil moisture and porosity, which are common traits of compacted soils. It is possible that the superior traffic tolerance of 'Sea Isle l' (compared with 'Tifway') may be due to its ability to grow in compacted soil conditions. Additional research is needed to determine intraspecific mechanisms of traffic tolerance in seashore paspalum.

\section{Conclusion}

Three of the four seashore paspalum cultivars evaluated (Salam, Sea Isle 1, and Sea Dwarf) exhibited traffic tolerance greater than 'Tifway' hybrid bermudagrass. After applying 90 passes (45 simulated professional football games) with the CTS, 'Salam', 'Sea Isle 1', and 'Sea Dwarf' were most tolerant of simulated traffic, 'Sea Isle 2000' was least tolerant of simulated traffic, and 'Tifway' hybrid bermudagrass ranked intermediate. Differences in traffic tolerance may be related to shoot density; 'Salam' and 'Sea Dwarf' (two of the three most traffic-tolerant cultivars) measured highest in shoot density, 'Sea Isle 2000' (the least traffic-tolerant cultivar) measured lowest in shoot density, and 'Sea Isle l' seashore paspalum and 'Tifway' hybrid bermudagrass ranked intermediate. The improved traffic tolerance of certain seashore paspalum cultivars may also be a function of their ability to grow in compacted soil conditions.

These preliminary data suggest that certain seashore paspalum cultivars may be suitable for use on athletic fields in place of 'Tifway' hybrid bermudagrass. Additional traffic tolerance studies will be needed as newer seashore paspalum cultivars are introduced into the marketplace. Including multiple hybrid bermudagrass cultivars in these studies would allow for interspecific comparisons to be made as well.

\section{Literature cited}

American Society for Testing Materials. 2000. Annual book of standards. Vol. 15.07. End use products. Standard test method for shock-attenuation characteristics of natural playing surface systems using a lightweight portable apparatus. F1702-96. American Society for Testing Materials, West Conshohocken, PA.

Calhoun, R., L. Sorochan, J.N. Rogers III, and J.R. Crum. 2002. Optimizing cultural practices to improve athletic field performance. Michigan State Univ. Ext. Bul. E18Turf.

Carrow, R.N. 2005. Seashore paspalum ecotype responses to drought and root limiting stresses. U.S. Golf Assn. Turfgrass Environ. Res. Online 4(13):1-9.

Carrow, R.N. and A.M. Petrovic. 1992. Effects of traffic on turfgrass, p. 285-330. In: D.V. Waddington, R.N. Carrow, and R.C. Shearman (eds.). Agron. Monogr. 32. Agron. Soc. Amer., Crop Sci. Soc. Amer., Soil Sci. Soc. Amer., Madison, WI.

Clegg, B. 1976. An impact testing device for in situ base course evaluation. Austral. Road Res. Bur. Proc. 8:1-6.

Cockerham, S.T. and D.J. Brinkman. 1989. A simulator for cleated-shoe sports traffic on turfgrass research plots. California Turfgrass Cult. 39(3/4):9-10.

Duncan, R.R. and R.N. Carrow. 2000. Seashore paspalum: The environmental turfgrass. Ann Arbor Press, Chelsea, MI.

Henderson, J.J., J.L. Lanovaz, J.R. Rogers, III, J.C. Sorochan, and J.T. Vanini. 2005. A new apparatus to simulate athletic field traffic: The Cady Traffic Simulator. Agron. J. 97:1153-1157.

Henderson, R.L., D.V. Waddington, and C.A. Morehouse. 1990. Laboratory measurements of impact absorption on turfgrass and soil surfaces, p. 127-135. In: R.C. Schmidt, E.F. Hoerner, E.M. Milner, and C.A. Morehouse (eds.). Natural and artificial playing fields: Characteristics and safety features. Spec. Tech. Publ. 1073. American Society for Testing Materials, West Conshohocken, PA.

Huang, B., R.R. Duncan, and R.N. Carrow. 1997. Drought-resistance mechanisms of seven warm-season turfgrasses under surface soil drying II. Root aspects. Crop Sci. 37:1863-1869.

Jiang, Y., R. Duncan, and R.N. Carrow. 2004. Assessment of low light tolerance of seashore paspalum and bermudagrass. Crop Sci. 44:587-594.
Kopec, D.M., J.L. Walworth, J.J. Gilbert, G.M. Sower, and M. Pessarakli. 2007. 'Sea Isle 2000' paspalum putting surface response to mowing height and nitrogen fertilizer. Agron. J. 99:133-140.

Lee, G., R.R. Duncan, and R.N. Carrow. 2004. Salinity tolerance of seashore paspalum ecotypes: Shoot growth responses and criteria. HortScience 39:1138-1142.

Marcum, K.B. and C.L. Murdoch. 1990. Growth responses, ion relations, and osmotic adaptations of eleven C4 turfgrasses to salinity. Agron. J. 82:892-896.

McCarty, L.B. and G. Miller. 2002. Managing bermudagrass turf. Ann Arbor Press, Chelsea, MI.

Minner, D.D., J.H. Dunn, S.S. Bughrara, and B.S. Fresenburg. 1993. Traffic tolerance among cultivars of Kentucky bluegrass, tall fescue, and perennial ryegrass. Intl. Turfgrass Soc. Res. J. 7:687-694.

Rogers III, J.N., D.V. Waddington, and J.C. Harper. 1988. Relationships between athletic field hardness and traction vegetation, soil properties, and maintenance practices. Pennsylvania State Univ., College of Agr. Expt. Sta., Prog. Rpt. 393.

Trenholm, L.E., R.N. Carrow, and R.R. Duncan. 2000. Mechanisms of wear tolerance in seashore paspalum and bermudagrass. Crop Sci. 40:1350-1357.

Trenholm, L.E., R.R. Duncan, and R.N. Carrow. 1999. Wear tolerance, shoot performance, and spectral reflectance of seashore paspalum and bermudagrass. Crop Sci. 39:1147-1152.

U.S. Golf Association. 2007. United States Golf Association recommendations for a method of putting green construction. 23 June 2008. <http://www.usga.org/ turf/course_construction/green_articles / putting_green_guidelines.html $>$.

Vanini, J.T., J.J. Henderson, J.C. Sorochan, and J.N. Rogers, III. 2007. Evaluating traffic stress by the Brinkman Traffic Simulator and the Cady Traffic Simulator on a Kentucky bluegrass stand. Crop Sci. 47:780-784.

Wiecko, G. 2003. Ocean water as a substitute for postemergence herbicides in tropical turf. Weed Technol. 17:788791.

Zebarth, B.J. and R.W. Sheard. 1985. Impact and shear resistance of turfgrass racing surfaces for thoroughbreds. Amer. J. Vet. Res. 46:778-784. 